\title{
Diabetes Mellitus ve Obezite Hastalarında Üriner Sistem Enfeksiyonu: Geriye Dönük Değerlendirme
}

\author{
Urinary System Infection at Diabetes Mellitus and Obesity Patients: A Retrospective Evaluation
}

\begin{abstract}
Özge KILINÇEL ${ }^{1 *}$, Cihadiye Elif ÖZTÜRK ${ }^{2}$, Handan ANKARALI ${ }^{3}$, Semih BOLU $^{4}$, Elif ÖNDER Özlem ADMIŞ$^{6}$
Atatürk Devlet Hastanesi Tibbi Mikrobiyoloji Bölümü, Düzce; $\quad{ }^{2}$ Düzce Üniversitesi Tip Fakültesi Tibbi Mikrobivoloïi AD, Diüzce; $\quad{ }^{3}$ Istanbul Medenivet Üniversitesi Tip Fakültesi Biyoistatistik ve Tip Bilisim AD, İstanbul; ${ }^{4}$ Adlvaman Üniversitesi Eğitim ve Arasstrma Hastanesi Cocuk Endokrinolojisi Kliniği, Adtvaman; ${ }^{5}$ Kanuni Sultan Süleyman Eğitim ve Arasttrma Hastanesi Endokrinoloji ve Metabolizma Hastallklarn Kliniği, İstanbul; ${ }^{6}$ Erzincan Binali Ylldırtm Üniversitesi Mengücek Gazi Eğitim ve Araştrtrma Hastanesi Tibbi Biyokimya Bölümü, Erzincan
\end{abstract}

\section{$\ddot{O Z Z}$}

Amaç: Bu çalışmada, hastanemiz erişkin ve çocuk endokrin polikliniklerinde diabetes mellitus (DM) ve obezite tanısı almış hastalarda, üriner sistem enfeksiyon etkeni olarak izole edilen patojenlerin dağılımı, bu patojenlerin antimikrobiyallere direnç oranları, glukozüri ve piyüri varlığının araştırılması amaçlanmıştır.

Gereç ve Yöntemler: Ocak 2012-Şubat 2014 tarihleri arasında Düzce Üniversitesi Tıp Fakültesi Hastanesi Erişkin ve Çocuk Endokrin polikliniklerinde DM ve obezite tanısı almış 107 hastaya ait kayıtlar geriye dönük olarak incelenmiştir. Bu hastalardan alınan idrar örneklerinin biyokimyasal/mikrobiyolojik laboratuvar sonuçları değerlendirilmiştir. Verilerin istatistiksel değerlendirmesinde SPSS 22.0 programı ile Fisher Exact ve Pearson Chi-Square testleri kullanılmıştır.

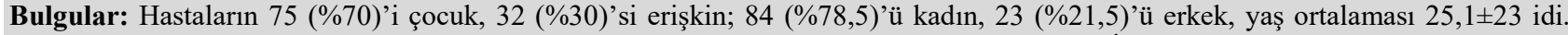
Diabetes mellitus ve obezite tanısı olan hasta sayısı sırasıyla $76(\% 71,0)$ ve $31(\% 29,0)$ idi. İdrar kültürlerinin $28(\% 26)$ 'inde (DM tanılı hastaların \%30,2'si ve obezite tanılı hastaların \%16,1'inde) bakteri üremesi olmuştur. Etken olarak en sık E. coli saptanmıştır. Piyüri ve glikozüri olan hastalarda daha fazla bakteri üremesi saptanmış olup, piyüri-bakteri üremesi arasında istatistiksel olarak anlamlı ilişki bulunmuşken, glikozüri ile anlamlı ilişki tespit edilmemiştir.

Sonuç: Glukozürinin, her ne kadar enfeksiyon riskini artırsa da tek başına belirleyici bir parametre olamayacağı ancak hastaların mevcut risk göz önünde tutularak değerlendirilmeleri gerektiği; ayrıca piyüri varlığı ile idrar yolu enfeksiyonu arasında kuvvetli bir ilişki olduğu görülmüştür. Ancak tam idrar tetkiki sonucuna göre ampirik tedaviye başlamak yerine idrar kültüründe izole edilen etkene ve duyarlılık profiline göre antibiyotik tedavisinin başlanmasının uygun olacağı düşünülmüştür.

Anahtar kelimeler: Diabetes mellitus; üriner sistem enfeksiyonu; glukozüri; obezite; piyüri.

\begin{abstract}
Aim: In this study, it was aimed to investigate the distribution of isolated pathogens, the resistance rates of these pathogens to antimicrobials, presence of glycosuria and pyuria in patients with diabetes mellitus (DM) and obesity in adult and pediatric endocrine outpatient clinics with urinary system infections.

Material and Methods: Between January 2012 and February 2014, records of 107 patients with DM and obesity in Duzce University Medical Faculty Hospital Adult and Pediatric Endocrine outpatient clinics were retrospectively reviewed. Biochemical/microbiological laboratory results of urine specimens taken from these patients were evaluated. Fisher Exact and Pearson Chi-Square tests were used with statistical evaluation of SPSS 22.0 program.

Results: Thirty-two $(70 \%)$ of the patients were children, $75(30 \%)$ are adults; $84(78.5 \%)$ were female, $23(21.5 \%)$ were male, mean of ages $25.1 \pm 23$. Number of patients with diabetes and obesity were $76(71.0 \%)$ and $31(29.0 \%)$, respectively. Bacterial growth occurred $28(26 \%)$ of urine cultures $(23(30.2 \%)$ of patients with DM, $5(16.1 \%)$ of patients with obesity). E. coli was detected most frequently as causative agent. In patients with pyuria and glycosuria, more bacterial growth were detected and statistically significant correlation was found between pyuria and bacterial growth, but no significant relationship was found with glycosuria.

Conclusion: Although glycosuria may increase the risk of infection, it may not be a determining parameter alone, but patients should be assessed considering the current risk; it has also been found that there is a strong relationship between the presence of the pyuria and urinary tract infection. However, it is considered appropriate to start antibiotic treatment according to the causative agent and sensitivity profile isolated in urine culture rather than to start empirical treatment according to the complete urine analysis result.
\end{abstract} Keywords: Diabetes mellitus; urinary system infection; glycosuria; obesity; pyuria. 


\section{GIIRIS}

Üriner sistem enfeksiyonu (ÜSE) olgularının polikliniklere en yüksek oranda başvuran hasta gruplarından biri olduğu ve özellikle diabetes mellitus (DM) gibi endokrin bir rahatsızlı̆ ${ }_{1}$ olan hasta popülâsyonunda ÜSE riskini artıran nörojen mesane, glukozüri gibi bazı faktörler olduğu bilinmektedir (1). DM tanılı hastalardaki ÜSE riski diğer popülâsyonlara göre daha fazladır; ancak enfeksiyon etkenleri farklılık göstermemektedir. Ayrıca yapılan çalışmalarda elde edilen klinik kanıtlar diyabetli hastalardaki ÜSE tedavisinin güç olduğunu ortaya koymaktadır. ÜSE tedavisi diyabetik olmayanlarla aynıdır ancak bu hastaların yakın izlemi gerekir. Çünkü DM tanılı hastalarda görülen ÜSE diyabetik ketoasidoz, sepsis, perinefrik apse, piyelonefrit ve papiller nekroza yol açabilmektedir (2-4).

Çoğu ÜSE'ye intestinal sistem mikrobiyotasında bulunan mikroorganizmalar neden olmaktadır. Altta yatan endokrin bir rahatsızlık olsun veya olmasin idrar yolu enfeksiyon etkenleri arasında ilk sirayı Escherichia coli almaktadı; bunu diğer enterik bakteriler, Pseudomonas spp. Grup B streptokok ve Candida spp. izlemektedir $(3,5)$.

Toplumda sık görülen bu tür enfeksiyonlara predispozisyon oluşturan faktörler ile enfeksiyon etkenlerinin ve tedavide seçilecek antibiyotiklere karşı duyarlılık oranlarının bilinmesi tedavi protokollerinin belirlenmesi bakımından önem arz etmektedir. $\mathrm{Bu}$ çalışmada, hastanemiz erişkin ve çocuk endokrin polikliniklerinde DM ve obezite tanısı almış hastalarda, ÜSE etkeni olarak izole edilen patojenlerin dağılımı, bu patojenlerin antimikrobiyallere direnç oranları, glikozüri ve piyüri varlığının araştırılması amaçlanmıştır.

\section{GEREC VE YÖNTEMLER}

Ocak 2012-Şubat 2014 tarihleri arasında Düzce Üniversitesi Tıp Fakültesi Hastanesi Erişkin ve Çocuk Endokrin polikliniklerinde DM ve obezite tanısı almış 107 hastaya ait kayıtlar geriye dönük olarak incelenmiştir. Hastaların 32 (\%29,9)'si erişkin ve 75 $(\% 70,1)$ 'i çocuk endokrin polikliniklerinde kayıtlı hastalardır. Bu hastalardan istenmiş olan idrar kültürü ve tam idrar tetkiki sonuçları değerlendirilmiştir.

İdrar örnekleri standart prosedürlere göre idrar kontrolü olanlarda steril kaplarla, idrar kontrolü olmayanlarda steril idrar torbası ile alınmıştır (6). İdrar örnekleri laboratuvara geldikten sonra \%5 koyun kanlı agar (HiMedia, Hindistan) ve Eosin Metilen Blue (HiMedia, Hindistan) agara ekilerek $37^{\circ} \mathrm{C}^{\prime}$ de $18-24$ saat inkübe edilmiştir. İnkübasyon sonunda çocuklarda $\geq 10^{3} \mathrm{cfu} / \mathrm{ml}$, erişkinlerde ise $\geq 10^{5}$ cfu/ml üreme saptanan suşların tanımlanmasında Gram negatif bakteriler için koloni morfolojisi, oksidaz testi, Triple Sugar İron Agar (HiMedia, Hindistan), Simmons' Citrate Agar (HiMedia, Hindistan), Sülfit İndol Motility Agar (HiMedia, Hindistan) ve Üre Agar (HiMedia, Hindistan) aktiviteleri; Gram pozitif bakteriler için koloni morfolojisi, kanlı agarda hemoliz özelliği, katalaz reaksiyonu, tüp koagülaz testi, Bile Esculin Agar (HiMedia, Hindistan) ve \%6,5 $\mathrm{NaCl}$ Agar aktiviteleri kullanılmışır. Antibiyotik duyarlılıkları Clinical and Laboratory Standards Institute (CLSI) kriterlerine uygun olarak Kirby Bauer disk difüzyon testi ile saptanmıştır. Gerekli durumlarda tanımlama ve antibiyotik duyarlılık testi için Vitek2 Otomatize Sistem (bioMerieux, ABD) kullanılmıştır. Glukozüri ve piyüri varlığı ise tam idrar tetkikine (TiT) (FUS-100/H800 tam otomatik idrar analiz sistemi, Dirui, Çin) göre belirlenmiş̧ir. Çalışma için Düzce Üniversitesi Tıp Fakültesi Etik Kurulu'ndan 2018/163 sayılı karar ile etik kurul izni alınmıştır.

\section{İstatistiksel Analiz}

İstatistiksel değerlendirmede SPSS 22.0 programı kullanılmıştır. Hastaların klinik tanısı ve TİT sonuçları ile kültürde üreme olması arasındaki ilişki Fisher Exact ve Pearson Chi-Square testleri ile belirlenmiştir.

\section{BULGULAR}

Hastaların $84 \quad(\% 78,5)$ 'ü kadın, 23 (\%21,5)'ü erkek, yaş ortalaması $25,1 \pm 23$ (en az=3, en fazla=78) olarak saptanmıştır. Hastaların $32(\% 29,9)$ 'si erişkin ve $75(\% 70,1)$ 'i çocuk endokrin polikliniklerinde kayıtlı hastalardır. Erişkin polikliniğinde hiç obezite tanılı hasta olmayıp bu poliklinikteki 32 hastanın tamamı
DM tanısı almıştır. Çocuk polikliniğindeki hastaların ise 44 $(\% 58,7)$ 'ü DM tanılı ve $31(\% 41,3)$ 'i obezite tanılı hastalardır. İncelenen 107 idrar örneğinin toplam $28(\% 26,2)$ 'inde (DM tanılı hastaların 23(\%30,3)'ü, obezite tanılı hastaların $5(\% 16,1)$ 'i) üreme olmuştur. Hastalar klinik tanılarına göre irdelendiğinde DM tanılı hastaların kültürde üreme oranları obezite tanılı hastalara oranla yüksek olmasına karşın aralarında istatistiksel olarak anlamlı fark saptanmamıştır $(\mathrm{p}=0,131)$. Erişkin ve çocuk polikliniklerine göre ayrı ayrı değerlendirildiğinde, erişkin polikliniğindeki DM tanılı hastaların $14(\% 43,8)$ 'ünde üreme görülmüştür. Çocuk polikliniğindeki DM tanılı hastaların 9 $(\% 20,5)$ 'unda ve obezite tanılı hastaların $5(\% 16,1)$ 'inde üreme olmuş, aralarındaki fark istatistiksel olarak anlamlı bulunmamıştır $(\mathrm{p}=0,636)$. Hastaların poliklinik ve tanıya göre dağılımları, üreme durumları Tablo 1'de gösterilmiştir.

Üreme olan 28 idrar kültüründe patojenlerin dağılımı incelendiğinde 20 adet Gram negatif bakteri ve sekiz adet Gram pozitif bakterinin ürediği görülmüştür. Üreyen patojenlerin 14'ü E. coli, dördü Klebsiella pneumoniae, biri Enterobacter spp., biri Proteus mirabilis, ikisi Staphylococcus aureus, ikisi koagülaz negatif stafilokok (KNS) ve dördü Enterococcus spp. olarak tanımlanmıştır. E. coli suşlarından üçü genişlemiş spektrumlu beta laktamaz pozitif, $S$. aureus suşlarından biri ise metisiline dirençli $S$. aureus olarak tespit edilmiştir. Bakterilerin antibiyotiklere direnç oranları Tablo 2'de gösterilmiştir.

Tablo 1. Örneklerdeki üreme sayılarının gönderildiği poliklinik ve hastaların tanısına göre dağı̆lımı (\%)

\begin{tabular}{cccccc}
\hline & Üreme & $\begin{array}{c}\text { DM } \\
(\mathbf{n}=\mathbf{7 6})\end{array}$ & $\begin{array}{c}\text { Obezite } \\
(\mathbf{n}=\mathbf{3 1})\end{array}$ & $\mathbf{p}$ & $\begin{array}{c}\text { Toplam } \\
(\mathbf{n}=107)\end{array}$ \\
\hline Erişkin Endokrin & $(+)$ & $14(43,8)$ & 0 & - & $14(43,8)$ \\
Polikliniği (n=32) & $(-)$ & $18(56,2)$ & 0 & - & $18(56,2)$ \\
\hline Çocuk Endokrin & $(+)$ & $9(20,5)$ & $5(16,1)$ & \multirow{2}{*}{0,636} & $14(18,7)$ \\
Polikliniği (n=75) & $(-)$ & $35(79,5)$ & $26(83,9)$ & & $61(81,3)$ \\
\hline \multirow{2}{*}{ Genel (n=107) } & $(+)$ & $23(30,3)$ & $5(16,1)$ & \multirow{2}{*}{0,131} & $28(26,2)$ \\
& $(-)$ & $53(69,7)$ & $26(83,9)$ & & $79(73,8)$ \\
\hline
\end{tabular}

DM: Diabetes Mellitus, (+): Üreme var, (-): Üreme yok

Tablo 2. Kültürde üreyen bakterilerin antibiyotiklere direnç oranları (\%)

\begin{tabular}{|c|c|c|c|}
\hline İzole Edilen Bakteri & 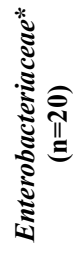 & 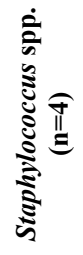 & 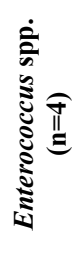 \\
\hline Ampisilin & 85 & 100 & 25 \\
\hline Piperasilin -Tazobaktam & 10 & - & - \\
\hline Sefoksitin & 5 & 75 & - \\
\hline Sefotaksim & 15 & - & - \\
\hline İmipenem & 0 & - & - \\
\hline Gentamisin & 30 & 0 & - \\
\hline Amikasin & 0 & - & - \\
\hline Siprofloksasin & 30 & 0 & 0 \\
\hline Levofloksasin & 20 & 0 & 0 \\
\hline Trimetoprim-Sulfometoksazol & 35 & 25 & - \\
\hline Fosfomisin & 0 & - & - \\
\hline Eritromisin & - & 75 & 0 \\
\hline Klindamisin & - & 75 & - \\
\hline Penisilin & - & 100 & 25 \\
\hline Oksasilin & - & 75 & - \\
\hline Linezolid & - & 0 & 0 \\
\hline Vankomisin & - & 0 & 0 \\
\hline Tetrasiklin & - & 25 & 0 \\
\hline Gentamisin Yüksek Düzey & - & - & 0 \\
\hline
\end{tabular}


TİT sonuçları değerlendirildiğinde; çalışmaya dâhil edilen 107 hastanın $28(\% 26,2)$ 'inde sadece glukozüri, $27(\% 25,2)$ 'sinde sadece piyüri, $11(\% 10,3)$ 'inde hem glukozüri hem de piyüri görülmüştür. Kırk bir $(\% 38,3)$ hastada ise glikozüri ve piyüri varlığ1 saptanmamıştır. TİT sonuçlarına göre üreme oranları incelendiğinde; kültürde üreme oranlarının istatistiksel olarak anlamlı farklılık gösterdiği görülmüştür $(p<0,001)$. Hem glukozüri hem de piyüri pozitif olan 11 hastanın idrar kültüründeki üreme oran $\% 81,8$ iken, sadece glukozüri pozitif olan 28 hastada bu oranın $\% 14,3$ olduğu, sadece piyüri pozitif olan 27 hastada \%48,1 ve ikisi de negatif olan 41 hastada ise $\% 4,9$ olduğu görülmüştür (Tablo 3 ).

Genel olarak bakıldığında, toplam $39(\% 36,4)$ hastada glukozüri ve toplam $38(\% 35,5)$ hastada piyüri varlığı görülmüştür. Kültür sonucunda üreme olan ve olmayanların glukozüri pozitiflikleri karşılaştırıldığında üreme olanların $13(\% 46,4)$ 'ünde ve üreme olmayanların $26(\% 32,9)$ 'sında glukozüri pozitifliği görülmüştür. $\mathrm{Bu}$ fark istatistiksel olarak anlamlı bulunmamıştır $(\mathrm{p}=0,202)$. Kültür sonucunda üreme olan ve olmayanların piyüri pozitiflikleri karşılaştırıldığında ise üreme olan 28 hastanın 22 $(\% 78,6)$ 'sinde ve üreme olmayan 79 hastanın $16(\% 20,2)$ 'sında piyüri pozitifliği saptanmış ve bu farkın istatistiksel olarak anlamlı olduğu görülmüştür $(\mathrm{p}<0,001)$. Ayrıca DM tanılı hastalar içinde kültürde üreme olan kişilerde piyüri pozitifliği $(\% 78,3)$ üreme olmayanlara $(\% 22,6)$ göre istatistiki olarak anlaml düzeyde yüksek bulunurken $(\mathrm{p}<0,001)$, glukozüri pozitifliği açısından üreme olanlarla $(\% 56,5)$, üreme olmayanlar $(\% 49,1)$ arasında anlamlı bir farkın olmadığı belirlenmiştir $(\mathrm{p}=0,550)$. Tanıs1 obezite olan hastalarda, piyüri pozitifliği açısından kültürde üreme olan $(\% 80,0)$ ve olmayanlar $(\% 15,4)$ arasında anlamlı fark bulunurken ( $\mathrm{p}=0,010)$, üreme olan ve olmayanlarda glukozüri pozitifliği saptanmamıştır (Tablo 4).

Tablo 3. Glukozüri ve piyüri değerlerinin tanı ve üreme durumuna göre dağılımı

\begin{tabular}{ccccccc}
\hline & Üreme & $\begin{array}{c}\mathbf{G}(+) \\
(\mathbf{n = 2 8})\end{array}$ & $\begin{array}{c}\mathbf{P}(+) \\
(\mathbf{n}=\mathbf{2 7})\end{array}$ & $\begin{array}{c}\mathbf{G P}(+) \\
(\mathbf{n}=\mathbf{1 1})\end{array}$ & $\begin{array}{c}\mathbf{G P}(-) \\
(\mathbf{n}=\mathbf{4 1})\end{array}$ & $\mathbf{p}$ \\
\hline $\begin{array}{c}\mathrm{DM} \\
(\mathrm{n}=76)\end{array}$ & $(+)$ & 4 & 9 & 9 & 1 & \\
\hline $\begin{array}{c}\text { Obezite } \\
(\mathrm{n}=31)\end{array}$ & $(+)$ & 24 & 10 & 2 & 17 & \\
\hline $\begin{array}{c}\text { Genel } \\
(\mathrm{n}=107)\end{array}$ & $(+)$ & 0 & 4 & 0 & 22 & \\
\hline
\end{tabular}

$\overline{\mathrm{G}(+) \text { : Sadece glukozüri pozitif, } \mathrm{P}(+) \text { : Sadece piyüri pozitif, } \mathrm{GP}(+) \text { : Hem glukozüri }}$ hem de piyüri pozitif, GP(-): Hem glukozüri hem de piyüri negatif, DM: Diabetes Mellitus, (+): Üreme var, (-): Üreme yok

Tablo 4. Üreme durumunun toplam glukozüri ve toplam piyüri değerlerine göre dağılımı*

\begin{tabular}{|c|c|c|c|c|}
\hline \multirow{3}{*}{$\begin{array}{c}\text { DM } \\
(n=76)\end{array}$} & & $\begin{array}{c}\text { Üreme Olan } \\
(\mathrm{n}=\mathbf{2 3})\end{array}$ & $\begin{array}{c}\text { Üreme Olmayan } \\
(\mathrm{n}=53)\end{array}$ & $\mathbf{p}$ \\
\hline & Glukozüri & $13(56,5)$ & $26(49,1)$ & 0,550 \\
\hline & Piyüri & $18(\% 78,3)$ & $12(\% 22,6)$ & $<0,001$ \\
\hline \multirow{3}{*}{$\begin{array}{c}\text { Obezite } \\
(\mathrm{n}=31)\end{array}$} & & $\begin{array}{c}\text { Üreme Olan } \\
(n=5)\end{array}$ & $\begin{array}{c}\text { Üreme Olmayan } \\
(n=26)\end{array}$ & $\mathbf{p}$ \\
\hline & Glukozüri & 0 & 0 & - \\
\hline & Piyüri & $4(\% 80,0)$ & $4(\% 15,4)$ & 0,010 \\
\hline \multirow{3}{*}{$\begin{array}{c}\text { Genel } \\
(\mathrm{n}=107)\end{array}$} & & $\begin{array}{c}\text { Üreme Olan } \\
(n=28)\end{array}$ & $\begin{array}{c}\text { Üreme Olmayan } \\
\qquad(n=79)\end{array}$ & $\mathbf{p}$ \\
\hline & Glukozüri & $13(46,4)$ & $26(32,9)$ & 0,202 \\
\hline & Piyüri & $22(78,6)$ & $16(20,2)$ & $<0,001$ \\
\hline
\end{tabular}

*Toplam Glukozüri $(n=39)$ : Sadece glukozuri pozitif olan hastalar $(n=28)$ ile hem glukozüri hem de piyüri pozitif olan hastaların $(\mathrm{n}=11)$ tümü, Toplam Piyuri $(\mathrm{n}=38)$ : Sadece piyüri pozitif olan hastalar $(n=27)$ ile hem glukozüri hem de piyüri pozitif olan hastaların ( $\mathrm{n}=11)$ tümü dahil edilmiştir.

\section{TARTISMA}

ÜSE toplumda en sık görülen enfeksiyonlardan biridir. Dünya genelinde her yıl yaklaşı 150 milyon ÜSE olgusu ile karşılaşılmaktadır (1). DM tanılı hastalarda ise ÜSE, normal popülâsyona göre daha sik görülmekte ve bu durum genellikle komplikasyonlarla seyretmektedir (2). Çalışmamızda DM tanılı hastaların \%30,2'sinde üreme tespit edilmiştir. Yapılan bir çalışmada DM tanılı hastalara ait idrar kültürlerindeki üreme oranı \%21 olarak saptanmıştır (7). Başka bir çalışmada ise aynı oran \%22,5 olarak belirlenmiştir (8). Çalışmamızın diğer çalışmalarla uyumlu olduğu gözlenmiştir. Ancak aynı oranı Feleke ve ark. (9) \%10,4, Yeshitela ve ark. (10) \%14, Yismaw ve ark. (11) \%17,8, Samuel ve ark. (12) ise \%17,3 olarak raporlamıştır. $\mathrm{Bu}$ çalışmalarda saptanan değerlerin bizim çalışmamızla kıyaslandığında daha düşük olduğu saptanmıştır. Değerler arasındaki bu farkın, coğrafi bölge farklılı̆̆ 1 , konak faktörü, toplumun sosyal alışkanlıkları, kişisel hijyen standartları ve sağlı eğitimi uygulamaları gibi faktörlerden kaynaklanabileceği düşünülmüştür. Genel popülâsyondaki idrar kültürlerinin incelendiği çalışmalarda ise Temiz ve ark. (13) idrar kültüründeki üreme oranını $\% 16$, Çoban ve ark. (14) \%3,7, Çalışkan ve ark. (15) ise \%20,8 olarak saptamışlardır. Çalışmamızda da literatürle uyumlu olarak DM tanılı hastaların idrar kültürlerindeki üreme oranlarının genel popülâsyona göre daha yüksek olduğu gözlenmiştir.

DM tanılı hastalardaki ÜSE riski diğer popülasyonlara göre daha fazla olmasına rağmen enfeksiyon etkenleri farklılık göstermemektedir (4). Enfeksiyona neden olan mikroorganizmalar en s1k Enterobacteriaceae ailesinden olup $E$. coli genellikle ilk sırada yer almaktadır. Çalışmamızda da en sık olarak E. coli izole edilmiş olup; bunu Enterococcus spp., $S$. aureus, KNS, K. pneumoniae, Enterobacter spp. ve $P$. mirabilis izlemiştir. Hem dünyada hem de ülkemizde bu konuda yapılmış birçok çalışmada bu bakterilerin sıklık sıraları değişmekle birlikte en sık olarak E. coli'nin izole edildiği gösterilmiştir (12,16-20). $\mathrm{Bu}$ bulgumuzun literatürle uyumlu olduğu gözlenmiştir. Ancak diğer çalışmalardan farklı olarak ikinci s1klıkla ürettiğimiz bakteri Enterococcus spp.'dir. Enterococcus spp. izole edilen dört hastadan üçünün kısa süre önce kan glukoz seviyelerinin düzenlenmesi amaciyla serviste tedavi gördüğü saptanmıştır. Dolayısıyla bu etkenin toplum kökenli değil hastane kökenli enfeksiyon etkeni olduğu düşünülmüştür.

ÜSE'de ampisilin, amoksisilin-klavulonik asit, trimetoprimsülfometoksazol (SXT), fosfomisin, siprofloksasin, levofloksasin ve nitrofurantoin en siklıkla kullanılan oral ajanlardır. Bunlar içerisinde en fazla direnç ampisilin ve SXT için bildirilmektedir (21). Bu çalışmada izole edilen Enterobacteriaceae ailesinde yer alan bakteriler arasında $\% 85$ oranıyla en sık olarak ampisiline direnç görülmektedir. Bunu SXT (\%35), siprofloksasin (\%30), gentamisin (\%30), levofloksasin (\%20), sefotaksim (\%15), piperasilin-tazobaktam (TZP) (\%10) ve sefoksitin (\%5) izlemektedir. Fosfomisin, amikasin ve imipenem direnci gözlenmemiştir. Simkhada (7) ve Kahlmeter (22), toplam 17 ülkede komplike olmayan üriner sistem enfeksiyonu olan kadınlarda yaptığı çalışmada, en sık antibiyotik direncinin ampisiline karşı olduğunu tespit ederek, ampisilinin ÜSE tedavisinde iyi bir seçenek olmadığına dikkati çekmektedir. Temiz ve ark. (13) ampisilin direncini \%79,5, Gülcan ve ark. (21) \%64, Şahin ve ark. (23) \%77, Aral ve ark. (24) ise \%73 olarak saptamışlardır. Ampisilin için bildirilen direnç oranları yüksek olmakla birlikte çalışmamızda diğerlerine kıyasla daha yüksek tespit edilmiştir. Çalışmalar arasında zaman farkı olmasının ve gün geçtikçe dirençli suşların artışının bu farka neden olabileceği düşünülmüştür. $\mathrm{Bu}$ çalışmada ikinci en sık olarak \%35 oranıyla SXT direnci dikkat çekmektedir. Diyabetik hastalardaki ÜSE etkenlerinin antibiyotik duyarlılıklarının araştırıldığı bir çalıșmada SXT direnci \%30 olarak bulunmuş ve çalışmamızla uyumlu olduğu gözlenmiştir. Yapılan başka çalışmalarda ise Çoban ve ark. (14) SXT direncini \%38, Gülcan ve ark. (21) \%44, Ay ve ark. (25) 
ise E. coli'de $\% 42$, Klebsiella türlerinde $\% 25, P$. mirabilis'de $\% 48$ olarak bildirmişlerdir. Diyabetik - nondiyabetik ayrımı yapılmayan çalışmalarla kıyaslandığında saptadığımız SXT direnç oranının daha düşük olduğu gözlenmektedir. Bu durumun ise coğrafik bölge farkı ve genel popülasyon yerine seçilmiş hasta grubu ile çalışmamızdan kaynaklandığı düşünülmüştür. Yapılan çeşitli çalışmalarda kinolon direnciyle ilgili farklı oranlar bildirilmiştir. $\mathrm{Bu}$ oranlar $\% 8$ ve $\% 47$ arasında değişmektedir $(7,26,27)$. Bu çalışmada siprofloksasin direnci $\% 30$, levofloksasin direnci \%20 olarak saptanmıştır. Simkhada (7) yaptı̆̆ çalışmada siprofloksasin direncini \%20,2, Temiz ve ark. (13) \%38, Kibar ve ark. (28) \%25; levofloksasin direncini ise Gülcan ve ark. (21) \%27 olarak tespit etmişlerdir. Diğer çalışmalardan elde edilen sonuçların bizim çalışmamızla uyumlu olduğu gözlenmiş̧ir. Fosfomisin, idrarda dört saat gibi kısa sürede ulaştığı yüksek konsantrasyon nedeniyle, nonkomplike sistitin ampirik tedavisinde endikedir (29). Çalışmamızda fosfomisin direnci saptanmamıştır. Literatür incelendiğinde de oldukça düşük direnç oranları dikkat çekmektedir (30-32). Antimikrobiyal direnç oranlarımızın özellikle diyabetik hastaların dahil edildiği çalışmalara benzediği dikkat çekmektedir. Bununla birlikte genel hasta grubunu içeren çalışmalarla küçük farklılıklar gözlense de çok büyük fark olmadığı saptanmıştır.

DM tanılı hastalarda gözlenen hiperglisemi durumu glukozüriye neden olmaktadır (33). Glukozürinin de bakteriyel üremeyi artırıp fagositozu bozarak ÜSE'ye predispozisyon oluşturduğu bilinmektedir (34). Çalışmamızda glukozüri, kültürde üreme olan hastalarda, olmayanlara kıyasla daha yüksek oranda tespit edilmiş ancak iki grup arasında anlamlı fark saptanmadığı gözlenmiştir. İdrarda piyüri tespit edilmesi bakteriyel bir enfeksiyonu kuvvetle düşündürmektedir (35). Çalı̧̧mamızda idrar kültüründe üreme olan hastalarda, üreme olmayanlara kıyasla piyüri pozitifliği anlamlı derecede yüksek bulunmuştur. Yapılan çalışmalarda da bizim bulgumuzla uyumlu olarak ÜSE ile piyüri arasında ilişki olduğu ve enfeksiyon düzeyini göstermede de istatistiksel olarak önemli olduğu saptanmıştır (36).

Sadece DM tanılı hastalar irdelendiğinde; kültürde üreme olan kişilerde piyüri pozitifliği üreme olmayanlara göre istatistiki olarak anlamlı yüksek bulunurken, glukozüri pozitifliğinde anlamlı bir farkın olmadığı belirlenmiştir. Obezite tanısı olan hastalar arasında da piyüri pozitifliğinin kültürde üreme olanlarda, olmayanlara kıyasla anlamlı düzeyde yüksek olduğu saptanmıştır. $\mathrm{Bu}$ bulgunun da literatürle uyumlu olduğu gözlenmiştir (36).

Hem glukozüri hem de piyüri pozitif olan hastaların idrar kültüründeki üreme oranlarının, bunlardan sadece biri pozitif olan hastalar ile ikisi de negatif olan hastalara kiyasla istatistiksel olarak anlamlı düzeyde yüksek olduğu saptanmıştır. Önceki çalışmalarla da desteklenmiş olan, glukozürinin ÜSE riskini artırdığı ve piyürinin de ÜSE varlığını destekleyici bir bulgu olması çalışmamızın literatürle uyumlu olduğunu göstermektedir (34-36).

\section{SONUÇ}

Yaptığımız bu çalışmada amacımız DM ve obezite tanısı almış hastalardan gönderilen idrar örneklerinde enfeksiyona predispozisyon oluşturan faktörler, enfeksiyon etkeni olarak izole edilen patojenlerin dağılımı ve bu patojenlerin çeşitli antimikrobiyallere duyarlılı̆̆ının araştırılması idi. Sonuç olarak glukozürinin, her ne kadar enfeksiyon riskini artırsa da tek başına belirleyici bir parametre olamayacağı ancak hastaların mevcut risk göz önünde tutularak değerlendirilmeleri gerektiği; ayrıca piyüri varlığı ile ÜSE arasında kuvvetli bir ilişki olduğu görülmüştür. Ancak TİT sonucuna göre ampirik tedaviye başlamak yerine idrar kültüründe izole edilen etkene ve duyarlılık profiline göre antibiyotik tedavisinin başlanmasının uygun olacağı düşünülmüştür.

\section{KAYNAKLAR}

1. Cattel WR. Urinary infections in adults. Postgraduate Med J. 1985;61(720):907-13.

2. Bonadio M, Meini M, Gigli C, Longo B, Vigna A. Urinary tract infection in diabetic patients. Urol Int. 1999;63(4):2159.

3. Sağlam H. Diyabet ve enfeksiyonlar. Güncel Pediatri. 2004;2(1):44-52.

4. Geerlings SE. Urinary tract infections in patients with diabetes mellitus: epidemiology, pathogenesis and treatment. Int J Antimicrob Agents. 2008;31(Suppl 1):54-7.

5. Doğan M, Aydemir Ö, Feyzioğlu B, Baykan M. Çocukların idrar örneklerinden izole edilen bakteriler ve antibiyotik duyarlıl1kları. ANKEM Derg. 2013;27(4):206-12.

6. Baysallar M. Tıbbi mikrobiyoloji uzmanları için klinik örnekten sonuç raporuna uygulama rehberi üriner sistem örnekleri. 1. Bask1. Ankara: Çağhan Ofset Matbaacılık; 2015.

7. Simkhada R. Urinary tract infection and antibiotic sensitivity pattern among diabetics. Nepal Med Coll J. 2013;15(1):1-4.

8. Alimohammadi H, Fouladi N. Study of urinary tract infection in diabetic and non-diabetic patients and antibiotic sensitivity pattern of isolated organisms. Int $\mathrm{J}$ Antimicrob Agents. 2007;29(Supp1 2):S648.

9. Feleke Y, Mengistu Y, Enquselassie F. Diabetic infections: clinical and bacteriological study at Tikur Anbessa Specialized University Hospital, Addis Ababa, Ethiopia. Ethiop Med J. 2007;45(2):171-9.

10. Yeshitela B, Gebre-Selassie S, Feleke Y. Asymptomatic bacteriuria and symptomatic urinary tract infections (UTI) in patients with diabetes mellitus in Tikur Anbessa Specialized University Hospital, Addis Ababa, Ethiopia. Ethiop Med J. 2012;50(3):239-49.

11. Yismaw G, Asrat D, Woldeamanuel Y, Unakal CG. Urinary tract infection: Bacterial etiologies, drug resistance profile and associated risk factors in diabetic patients attending Gondar University Hospital, Gondar, Ethiopia. Euro J Exp Bio. 2012;2(4):889-98.

12. Samuel OO, Mathew AO, Mopelola DAA, Tosin OJA, Grace $\mathrm{AB}$, Anthony BO. Asymptomatic urinary tract infection in diabetic patients in Ago Iwoye, Ogun State, Nigeria. J Am Sci. 2014;10(4):72-8.

13. Temiz H, Akkoç H, Gül K. Laboratuarımızda idrar kültürlerinden izole edilen gram negatif bakterilerde antibiyotiklere direnç. Dicle Tip Derg. 2008;35(4):234-9.

14. Çoban B, Ülkü N, Kaplan H, Topal B, Erdoğan H, Baskın E. Five-year assessment of causative agents and antibiotic resistances in urinary tract infections. Türk Ped Arş. 2014;49(2):124-9.

15. Çalışkan E, Şahin İ, Öztürk CE, Yavuz MT, Ankaralı H, Türkmen-Albayrak H. Üriner sistem infeksiyonlarının tanısında kullanılan mikrobiyolojik yöntemlerin karşılaştırılması. Klimik Dergisi. 2013;26(1):9-12.

16. Bonadio M, Costarelli S, Morelli G, Tartaglia T. The influence of diabetes mellitus on the spectrum of uropathogens and the antimicrobial resistance in elderly adult patients with urinary tract infection. BMC Infect Dis. 2006;6:54.

17. Pargavi B, Mekala T, Selvi AT, Moorthy K. Prevalence of urinary tract infection (UTI) among diabetics patients in Vandavasi, Tamil Nadu, India. Int J Biotech. 2011;2(2):42-5.

18. Dündar D, Willke A, Sönmez TG. İdrar yolu infeksiyonu etkenleri ve antibiyotik duyarlılıkları. Klimik Derg. 2008;21(1):7-11.

19. Gazi H, Sürücüoğlu S, Kurutepe S. İdrar kültürlerinden izole edilen Gram negatif bakterilerde antibiyotiklere direnç. ANKEM Derg. 2007;21(1):19-22.

20. Yurtsever SG, Baran N, Şener AG, Çeken N, Kurultay N, Türker M. İdrar örneklerinden izole edilen mikroorganizmalar ve antibiyotiklere duyarlılıkları. Klimik Derg. 2006;19(2):60-2. 
21. Gülcan A, Aslantürk A, Gülcan E. İdrar kültürlerinden izole edilen mikroorganizmalar ve in vitro antibiyotik duyarlılık durumlar1. Abant Med J. 2012;1(3):129-35.

22. Kahlmeter G. An international survey of the antimicrobial susceptibility of pathogens from uncomplicated urinary tract infections: the ECO.SENS Project. J Antimicr Chemother. 2003;51(1):69-76.

23. Şahin İ, Şencan İ, Kaya D, Gülcan A, Öksüz Ş. Hastane infeksiyonu etkeni üropatojen Escherichia coli izolatlarının çesitli antibiyotiklere direnç durumu. ANKEM Derg. 2004;18(4):193-5.

24. Aral M, Kireçci E, Doğan SŞ. İdrar örneklerinden izole edilen gram negatif bakteriler ve antibiyotiklere direnç oranlarının retrospektif olarak değerlendirilmesi. Türk Mikrobiyol Cem Derg. 2011;41(4):139-42.

25. Ay S, Abut İşeri L, Duman B. İdrar örneklerinden izole edilen gram olumsuz mikroorganizmaların antibiyotiklere duyarlılıkları. İnönü Üniversitesi T1p Fak Derg. 2003;10(2):59-62.

26. Pullukçu H, Taşbakan MI, Aydemir S, Sipahi OR, Turhan A, Öznel MA, ve ark. İdrar kültürlerinden soyutlanan bakteriler ve çeşitli antibiyotiklere in-vitro duyarlılıklarının değerlendirilmesi. ANKEM Derg. 2006;20(1):26-30.

27. Akay H, Duranay M, Akay A. Üriner sistem enfeksiyonlarından izole edilen mikroorganizmaların dağılımı ve Escherichia coli suşlarında antibiyotik duyarlılığı. İst Tıp Fak Derg. 2006;69(1):1-4.

28. Kibar F, Yaman A, Dündar İH. İdrar örneklerinden izole edilen bakteriler ve antibiyotiklere duyarlılıkları. Türk Mikrobiyol Cem Derg. 2004;34(3):162-70.

29. Warren JW, Abrutyn E, Hebel JR, Johnson JR, Schaeffer AJ, Stamm WE. Guidelines for antimicrobial treatment of uncomplicated acute bacterial cystitis and acute pyelonephritis in women. Clin Infect Dis. 1999;29(4):74558.

30. Kart Yaşar K, Pehlivanoğlu F, Şengöz G. Alternatif tedavi seçeneği olarak fosfomisinin komplike üriner sistem infeksiyonlarından izole edilen GSBL pozitif Escherıchia coli suşlarına etkinliği. ANKEM Derg. 2011;25(1):12-6.

31. Köken G, Aşık G, Çiftci İH, Çetinkaya Z, Aktepe OC, Yılmazer M. Toplum kökenli üriner sistem infeksiyonu etkeni Escherichia coli suşlarında fosfomisin trometamol etkinliği. ANKEM Derg. 2008;22(1):23-7.

32. Arslan H, Azap OK, Ergönül O, Timurkaynak F, Urinary Tract Infection Study Group. Risk factors for ciprofloxacin resistance among Escherichia coli strains isolated from community-acquired urinary tract infections in Turkey. J Antimicrob Chemother. 2005;56(5):914-8.

33. Beğer T, Erdinçler TS, Çurgunlu A. Yaşlıda diabetes mellitus. Akademik Geriatri Dergisi [Internet]. 2009;1(1):2030. [Erişim Tarihi: 19.06.2018]. Erişim adresi: $\mathrm{http} / / / \mathrm{www}$.akadgeriatri.org/managete/fu_folder/200901/html/2009-1-1-020-030.htm\#.

34. Peleg AY, Weerarathna T, McCarthy JS, Davis TM. Common infections in diabetes: pathogenesis, management and relationship to glycaemic control. Diabetes Metab Res Rev. 2007;23(1):3-13.

35. Carroll KC, Diagnostic medical microbiology and clinical correlation. In: Brooks GF, Carroll KC, Butel JS, Morse SA, editors. Jawetz, Melnick \& Adelberg medical microbiology. 24th ed. New York: The McGraw-Hill Companies; 2010. p.712-8.

36. Kodner CM, Thomas Gupton EK. Recurrent urinary tract infections in women: Diagnosis and management. Am Fam Physician. 2010;82(6):638-43. 